\title{
Intramolecular Ring-opening Decomposition of Aryl Azetidines
}

Guoyun Bail, Thomas N. O’Connell", Michael A. Brodney\#, Christopher R. Butler\#, Lara C. Czabaniuk", Adam M. Gilbert", Erik A. LaChapelle*, Chao Li", Laura A. McAllister", Kevin Ogilvie ${ }^{\ddagger}$, Laurence Philippe", Romelia Salomon-Ferrer ${ }^{\ddagger}$, Michael J. Shapiro", Jeremy T. Starr", Daniel P. Uccello", Jane M. Withkal, Jiangli Yan", Matthew F. Brown" ${ }^{*}$

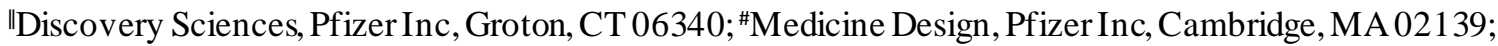

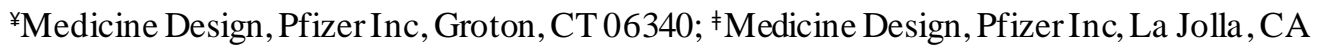

Supporting Information Contents

\begin{tabular}{|c|c|}
\hline Topic & Pages \\
\hline $\begin{array}{c}\text { NMR and MS methods for T1/2 and } \mathrm{pK}_{\mathrm{a}} \\
\text { assessment }\end{array}$ & $\mathrm{S} 2$ \\
\hline $\begin{array}{c}\text { MS method for determining mechanism of } \\
\text { decomposition }\end{array}$ & $\mathrm{S3}$ \\
\hline Compound Synthesis & S4-S15 \\
\hline
\end{tabular}




\section{NMR and MS Methods}

1) Sample preparation for NMR measurements

Compounds were dissolved in DMSO-d6 to make $40 \mathrm{mM}$ stocks. A few compounds had limited solubility and the concentrations were adjusted to $10 \mathrm{mM}$ in DMSO. $600 \mathrm{uL}$ was transferred to $5 \mathrm{~mm}$ NMR tubes for NMR measurements in DMSO.

2) NMR methods for $\mathrm{pK}_{\mathrm{a}}$ determination ${ }^{1}$ and ${ }^{15} \mathrm{~N}$ assignment.

2D NMR measurements were carried out on a Bruker Avance III $600 \mathrm{MHz}$ spectrometer equipped with an inverse triple resonance (TXI) $5 \mathrm{~mm}$ cryoprobe. $2 \mathrm{D}{ }^{1} \mathrm{H}-{ }^{13} \mathrm{C}$ HSQC and $\mathrm{HMBC}$ were acquired to allow for assignments of proton signals. $2 \mathrm{D}^{1} \mathrm{H}-{ }^{15} \mathrm{~N} \mathrm{HMBC}$ were collected to obtain ${ }^{15} \mathrm{~N}$ chemical shifts in DMSO.

3) $\mathrm{NMRT}_{1 / 2}$ measurements

NMR measurements were carried out on a Bruker Avance $500 \mathrm{MHz}$ spectrometer equipped with a direct observe $(\mathrm{DCH}) 5 \mathrm{~mm}$ cryoprobe or an inverse $\mathrm{BBO} 5 \mathrm{~mm}$ probe.

A fraction of the DMSO-d6 stock was added to a buffered solution $(\mathrm{pH}: 1.8,2.7$, or 7.0) with a final concentration of $1 \mathrm{mM}$ for the compound, and 5\% (v/v) for DMSO-d6 (for locking purpose). Time was recorded as " 0 " hour the moment the DMSO stock was added to the buffer.

The prepared NMR sample was quickly placed in the spectrometer magnet and allowed to reach thermal equilibrium at $298 \mathrm{~K}$ for at least $1 \mathrm{~min}$. Then a series of spectra were acquired using a standard solvent suppression pulse sequence (NOESYPR1D) into 16k data points over a spectral width of $16 \mathrm{ppm}$. -NMR spectra were acquired with 32 scans every 3 min until 24 hours or until at least $50 \%$ of the starting material degraded.

Following acquisition, the first experiment was phase-corrected, zero-filled to $64 \mathrm{k}$ data points and treated with an exponential window function equivalent to a line broadening of $1 \mathrm{~Hz}$. The same phase parameters were then used on all subsequent experiments for the rate measurement. The integration of a peak in the aromatic area was chosen to be used for the calculation of $T_{1 / 2}$. It was normalized to the integrated area of DMSO signal to minimize the differences between each spectrum, and $T_{1 / 2}$ was calculated from a plot of $\log$ [normalized $1 \mathrm{H}$ integral value] versus NMR data set acquisition start time (hours) using Microsoft Excel, where $T_{1 / 2}=\log (2) /$ slope of the line. ${ }^{2}$ 
4) Determination of Mechanism of Decomposition of Compound $\mathbf{1}$ by MS

Compound 1 was dissolved in $1 \mathrm{mM}$ in sodium phosphate buffer $(\mathrm{pH}=1)$ and transferred to a $3 \mathrm{~mm}$ NMR tube. ${ }^{1} \mathrm{H}$ NMR spectra were collected over the course of 2 days. A 5 uL aliquot was removed at $t=0,3,4$, and $21 \mathrm{hr}$. Each aliquot was immediately diluted with $0.5 \mathrm{~mL}$ of $100 \mathrm{mM}$ sodium phosphate buffer at $\mathrm{pH}$ $=7.3$ and subsequently analyzed by LC/MS.

Samples were injected onto an Agilent 1290 UHPLC (Wilmington, DE) coupled to an Agilent 6545XT QTOF mass spectrometer. The instrument was equipped with an Omega $C_{18} 2.1 \times 30 \mathrm{~mm} 1.6 \mu \mathrm{m}$ UHPLC column and an electrospray source operated in the positive ion mode. The instrument was tuned and calibrated to the manufacturer's specifications prior to running. Lock masses of 121.0509 and $922.008 \mathrm{~m} / \mathrm{z}$ were infused during acquisition to calibrate the run.

The mobile phase consisted of:

A) $0.1 \%$ formic acid in water

B) $0.1 \%$ formic acid in acetonitrile

Gradient A: B 98:2 hold for $6 \mathrm{~min}$; ramp to $60: 40$ by $10 \mathrm{~min}$, flush with $90: 10$ and re-equilibrate to $98: 2$ for 3 min. Flow rate was $0.4 \mathrm{~mL} / \mathrm{min}$.

A peak at 9 min with a mass of 220.1443 was consistent with compound 1 within 1 ppm accuracy. A peak at $1.2 \mathrm{~min}$ with an $\mathrm{m} / \mathrm{z}$ value of 193.0969 was consistent with the lactone intermediate 14 within $1.5 \mathrm{ppm}$ accuracy. A peak at 1.4 min with an $\mathrm{m} / \mathrm{z}$ value of 193.0969 was consistent with the lactam 15 within 1.5 ppm accuracy.

There was a clear conversion of compound 1 to lactone 14 at $3 \mathrm{hrs}$ and lactam 15 by $21 \mathrm{hrs}$. The structure of 15 was confirmed by NMR.

${ }^{1}$ Bezencon, J.; Wittwer, M. B.; Cutting, B.; Smiesko, M.;Wagner, B.; Kansy, M.; Ernst, B. pKa determination by $1 \mathrm{H}$ NMR spectroscopy - An old methodology revisited. Journal of Pharmaceutical and Biomedical Analysis, 2014, 93, 147-155.

2 Vanderhoeven, S. J.; Lindon, J.C.; Troke, J.; Nicholson, J. K.; Wilson, I. D. NMR spectroscopic studies of the transacylation reactivity of ibuprofen 1- $\beta$-O-acyl glucuronide. J. Pharm. Biomed. Ana. 2006, 41, 10021006. 


\section{Compound Synthesis}

Synthesis of ethyl azetidin-3-ylacetate (S4)

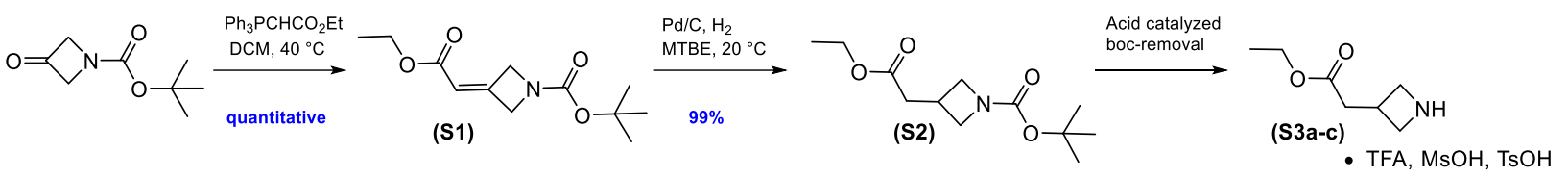

Step 1. Synthesis of tert-butyl 3-(2-ethoxy-2-oxoethylidene)azetidine-1-carboxylate (S1).

tert-Butyl 3-oxoazetidine-1-carboxylate (100 g, $584 \mathrm{mmol})$ was dissolved in dichloromethane (750 $\mathrm{mL})$, was cooled in an ice bath and vigorously stirred while (carboethoxymethylene)triphenylphosphorane (220 $\mathrm{g}, 631 \mathrm{mmol}$ ) was added portion-wise over 15 minutes. The reaction mixture was then heated to $40{ }^{\circ} \mathrm{C}$ for 4 hours, whereupon most of the dichloromethane was removed in vacuo. The resulting thick slurry was diluted with a mixture of hexanes and tert-butyl methyl ether $(2: 1,1 \mathrm{~L})$, and stirred at room temperature for 1.5 hours. Triphenylphos phine oxide was removed via filtration; the filter cake was washed with a 2:1 mixture of hexanes and tert-butyl methyl ether, and the combined filtrates were concentrated in vacuo. Silica gel chromatography (Eluent: 2:1 hexanes / tert-butyl methyl ether) afforded the product as a clear, slightly yellow oil. Yield: $141.8 \mathrm{~g}$, quantitative.

Step 2. Synthesis of tert-butyl 3-(2-ethoxy-2-oxoethyl)azetidine-1-carboxylate (S2).

A solution of S1 (141 g, $584 \mathrm{mmol})$ in tert-butyl methyl ether $(500 \mathrm{~mL})$ was placed in a Parr bottle and treated with $10 \%$ palladium on carbon ( $50 \%$ water by weight; $2.5 \mathrm{~g}$ ). The reaction vessel was evacuated and charged with nitrogen. This evacuation cycle was repeated several times, and then the bottle was pressurized to 40 psi with hydrogen and shaken for 30 minutes, whereupon the vessel was purged with additional nitrogen / vacuum cycles. The reaction mixture was filtered through a pad of diatomaceous earth and powdered cellulose, which was subsequently rinsed with tert-butyl methyl ether. The combined filtrates were concentrated in vacuo to provide the product as a clear, colorless oil. Yield: $140.1 \mathrm{~g}, 576$ mmol, 99\%. ${ }^{1} \mathrm{H}$ NMR (400 MHz, DMSO- $\left.d_{6}\right) \delta 4.04(\mathrm{q}, J=7.0 \mathrm{~Hz}, 2 \mathrm{H}), 3.99-3.85(\mathrm{~m}, 2 \mathrm{H}), 3.58-3.45(\mathrm{~m}, 2 \mathrm{H})$, 2.84-2.71(m, 1H), $2.62(\mathrm{~d}, J=7.4 \mathrm{~Hz}, 2 \mathrm{H}), 1.36(\mathrm{~s}, 9 \mathrm{H}), 1.17(\mathrm{t}, J=7.0 \mathrm{~Hz}, 3 \mathrm{H})$.

Step 3a. Synthesis of ethyl azetidin-3-ylacetate, trifluoroacetate salt (S3a).

Trifluoroacetic acid $(60 \mathrm{~mL})$ was added in a drop-wise manner to a solution of $\mathbf{S 2}(15.0 \mathrm{~g}, 61.6 \mathrm{mmol})$ in dichloromethane $(200 \mathrm{~mL})$ and the reaction mixture was stirred at room temperature for 2 hours. Removal of solvents in vacuo afforded the product as a pale yellow oil. Yield: $15.85 \mathrm{~g}, 61.62 \mathrm{mmol}$, quantitative. ${ }^{1} \mathrm{H}$ NMR (400 MHz, $\mathrm{CDCl}_{3}$ ) $\delta 8.23-7.99(\mathrm{br} \mathrm{s}, 1 \mathrm{H}), 7.99-7.77(\mathrm{br} \mathrm{s}, 1 \mathrm{H}), 4.41-4.27(\mathrm{~m}, 2 \mathrm{H}), 4.16$ (q, J=7.2 Hz, 2H), 4.11-3.99 (m, 2H), 3.40-3.25 (m, 1H), $2.74(\mathrm{~d}, J=7.2 \mathrm{~Hz}, 2 \mathrm{H}), 1.26(\mathrm{t}, J=7.2 \mathrm{~Hz}, 3 \mathrm{H})$.

Step 3b. Synthesis of ethyl azetidin-3-ylacetate, mesylate salt (S3b).

To S2 (690 mg, $2.84 \mathrm{mmol}$ ) and ethanol (15 ml) was added methanesulfonic acid ( $286 \mathrm{mg}, 0.193 \mathrm{mmol})$. The resulting mixture was stirred at $70{ }^{\circ} \mathrm{C}$ for 5 hours. The reaction mixture was cooled to room temperature, filtered and concentrated to give the title product as a gum. Yield: $700 \mathrm{mg}, 2.93 \mathrm{mmol}$, 
103\%. ${ }^{1} \mathrm{H}$ NMR (CHLOROFORM-d, $400 \mathrm{MHz}$ ) $\delta 8.93$ (br. s, $\left.1 \mathrm{H}\right), 8.80$ (br s, $\left.1 \mathrm{H}\right), 4.2-4.3(\mathrm{~m}, 2 \mathrm{H}), 4.0-4.2(\mathrm{~m}$, $2 \mathrm{H}$ ), 3.9-4.0 (m, $2 \mathrm{H}), 3.26$ (quind, $1 \mathrm{H}, J=8.0,16.3 \mathrm{~Hz}), 2.83(\mathrm{~s}, 3 \mathrm{H}), 2.74(\mathrm{~d}, 2 \mathrm{H}, J=7.5 \mathrm{~Hz}), 1.2-1.3(\mathrm{~m}, 3 \mathrm{H}$ )

Step 3c. Synthesis of ethyl azetidin-3-ylacetate, tosylate salt (S3c).

To S2 (1 g, $4.11 \mathrm{mmol})$ and ethyl acetate $(10 \mathrm{ml})$ was added p-toluenesulfonic acid (782 $\mathrm{mg}, 4.11 \mathrm{mmol})$. The resulting mixture was stirred at reflux for 60 hours. The reaction mixture was cooled to room temperature and concentrated to provide the title compound as an off-white solid. The material used without further purification. Yield: $1300 \mathrm{mg}, 4.11 \mathrm{mmol}, 100 \%$.

\section{Synthesis of (S4-S17)}

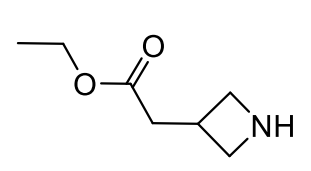

(S3)

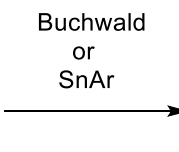

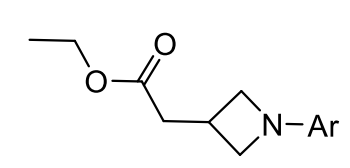

$\mathrm{Ar}=3$-pyridine $\mathbf{( S 4 )}$

4-pyridine(S6)

2-pyridine (S8)

phenyl (S10)

4-methoxyphenyl (S12)

4-cyanophenyl (S14)

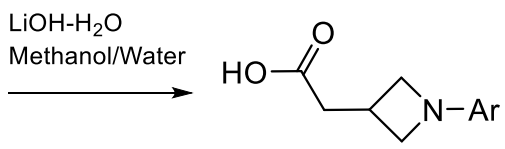

$\mathrm{Ar}=3$-pyridine (S5)

4-pyridine(S7)

2-pyridine (S9)

phenyl (S11)

4-methoxyphenyl (S13)

4-cyanophenyl (S15)

Synthesis of [1-(pyridin-3-yl)azetidin-3-yl]acetic acid (S5).

Step 1. Synthesis of ethyl [1-(pyridin-3-yl)azetidin-3-yl]acetate (S4).

A mixture of S3a (10.0 g, $38.9 \mathrm{mmol}), 3$-bromopyridine (16.6 g, $105 \mathrm{mmol}), 1,1$ '-binaphthalene-2,2'diylbis(diphenylphosphane) (BINAP; $8.7 \mathrm{~g}, 14 \mathrm{mmol}$ ), tris(dibenzylideneacetone)dipalladium(0) $\left(\mathrm{Pd}_{2}(\mathrm{dba})_{3} ; 6.4 \mathrm{~g}, 7.0 \mathrm{mmol}\right)$, and cesium carbonate $(91.0 \mathrm{~g}, 279 \mathrm{mmol})$ in toluene $(300 \mathrm{~mL})$ was heated at $90{ }^{\circ} \mathrm{C}$ for 16 hours. Most of the toluene was removed via concentration in vacuo, and the residue was diluted with water $(3 \times 200 \mathrm{~mL})$ and extracted with ethyl acetate $(3 \times 100 \mathrm{~mL})$. The combined organic layers were washed with saturated aqueous sodium chloride solution $(2 \times 100 \mathrm{~mL})$, dried over sodium sulfate, filtered, and concentrated under reduced pressure. Silica gel chromatography (Gradient: $17 \%$ to $20 \%$ ethyl acetate in petroleum ether) provided the product as a brown oil. Yield: $4.0 \mathrm{~g}, 18 \mathrm{mmol}, 46 \%$. Chemical Formula: C12H16N2O2, LCMS (ESI) $\mathrm{m} / \mathrm{z}$ : $[\mathrm{M}+\mathrm{H}]$ calcd: 220.1 ; found: $220.9 .{ }^{1} \mathrm{H} \mathrm{NMR}\left(400 \mathrm{MHz}, \mathrm{CDCl}_{3}\right) \delta$ 8.01 (dd, J=4.6, $1.3 \mathrm{~Hz}, 1 \mathrm{H}$ ), 7.85 (d, J=2.9 Hz, $1 \mathrm{H}$ ), 7.10 (dd, J=8.2, $4.7 \mathrm{~Hz}, 1 \mathrm{H}$ ), 6.71 (ddd, J=8.3, 2.8, $1.4 \mathrm{~Hz}$, $1 \mathrm{H}), 4.16$ (q, J=7.2 Hz, 2H), 4.11 (dd, J=7.9, $7.5 \mathrm{~Hz}, 2 \mathrm{H}$ ), 3.61 (dd, J=7.2, 5.6 Hz, 2H), 3.20-3.08 (m, $1 \mathrm{H}), 2.72$ (d, J=7.8Hz, 2H), $1.27(\mathrm{t}, J=7.2 \mathrm{~Hz}, 3 \mathrm{H}$ ).

Step 2. Synthesis of [1-(pyridin-3-yl)azetidin-3-yl]acetic acid (S5). 
Lithium hydroxide $(652 \mathrm{mg}, 27.2 \mathrm{mmol})$ was added to a solution of $\mathbf{S 4}(3.00 \mathrm{~g}, 13.6 \mathrm{mmol})$ in a mixture of methanol $(20 \mathrm{~mL})$ and water $(5 \mathrm{~mL})$. The reaction mixture was stirred at room temperature for 2 hours, whereupon it was cooled to $0{ }^{\circ} \mathrm{C}$, and concentrated hydrochloric acid was added until the $\mathrm{pH}$ of the reaction mixture reached 7 . Concentration in vacuo afforded the product. Yield: $3.3 \mathrm{~g}$, assumed quantitative. ${ }^{1} \mathrm{H}$ NMR $\left(400 \mathrm{MHz}\right.$, DMSO- $\left.d_{6}\right) \delta$ 7.91-7.82 (m, $\left.1 \mathrm{H}\right), 7.75(\mathrm{~s}, 1 \mathrm{H}), 7.17-7.07(\mathrm{~m}, 1 \mathrm{H})$, 6.80-6.71 $(\mathrm{m}, 1 \mathrm{H}), 3.97(\mathrm{dd}, J=7,7 \mathrm{~Hz}, 2 \mathrm{H}), 3.48(\mathrm{dd}, J=6,6 \mathrm{~Hz}, 2 \mathrm{H}), 3.02-2.89(\mathrm{~m}, 1 \mathrm{H}), 2.5(2 \mathrm{H}$, assumed; obscured by solvent peak).

\section{Synthesis of 2-(1-(pyridin-4-yl)azetidin-3-yl)acetic acid (S7)}

Step 1: Synthesis of ethyl 2-(1-(pyridin-4-yl)azetidin-3-yl)acetate (S6)

To a round bottomed flask was added S3a (500mg, $1.94 \mathrm{mmol}$ ), 4-iodopyridine (399mg, $1.94 \mathrm{mmol}$ ), 4,5Bis(diphenylphosphino)-9,9-dimethylxanthene $\quad\left(\begin{array}{llll}74.2 & \mathrm{mg}, & 0.128 & \mathrm{mmol}\end{array}\right)$, tris(dibenzylideneacetone)dipalladium(0) $(53.4 \mathrm{mg}, 0.058 \mathrm{mmol}$ ) and cesium carbonate $(2.53 \mathrm{~g}, 7.78$ $\mathrm{mmol})$. Anhydrous 1,4-dioxane $(30 \mathrm{ml})$ was then added and reaction vessel was purged with nitrogen and reaction heated at $100^{\circ} \mathrm{C}$ for $18 \mathrm{hrs}$. Reaction was then cooled to $20^{\circ} \mathrm{C}$, solids removed via filtration, and filtrate concentrated. The residue was purified via prep-TLC (dichloromethane : methanol.; 25:1) to afford desired product. Yield: 99mg, $0.449 \mathrm{mmol}, 23 \%)$.

Step 2: Synthesis of 2-(1-(pyridin-4-yl)azetidin-3-yl)acetic acid (S7)

To a solution of $\mathbf{S 6}(170 \mathrm{mg}, 0.772 \mathrm{mmol})$ in methanol $(4 \mathrm{ml})$ and water $(1 \mathrm{ml})$ was added lithium hydroxide $(37.0 \mathrm{mg}, 1.54 \mathrm{mmol})$ at $20^{\circ} \mathrm{C}$. The reaction mixture was stirred for $2 \mathrm{hrs}$ and then reaction cooled to $0^{\circ} \mathrm{C}$. The $\mathrm{pH}$ was adjusted to 7 with conc. $\mathrm{HCl}$ and reaction was concentrated in vacuo to provide desired product as a yellow solid that was used in the next step crude. Yield: $200 \mathrm{mg}, 1.04 \mathrm{mmol}, 135 \%$. ${ }^{1} \mathrm{H}$ NMR (400 MHz, MeOD) 6 7.97-8.06 (m, 2H), 6.31-6.41 (m, 2H), 4.10-4.20 (m, 2H), 3.69 (dd, J=5.52, 8.53 Hz, 2H), 3.06-3.20 (m, $1 \mathrm{H}), 2.54(\mathrm{~d}, J=7.53 \mathrm{~Hz}, 2 \mathrm{H})$

Synthesis of 2-(1-(pyridin-2-yl)azetidin-3-yl)acetic acid (S9)

Step 1: Synthesis of ethyl 2-(1-(pyridin-2-yl)azetidin-3-yl)acetate (S8)

To round bottomed flask was added S3a $(2.49 \mathrm{~g}, 9.69 \mathrm{mmol})$, 2-chloropyridine $(1.00 \mathrm{~g}, 8.81 \mathrm{mmol})$, cesium fluoride $(2.01 \mathrm{~g}, 13.2 \mathrm{mmol})$ and trimethylamine $(3.56 \mathrm{~g}, 35.2 \mathrm{mmol})$. To this was added dimethylsulfoxide $(35 \mathrm{ml})$ and reaction heated at $100^{\circ} \mathrm{C}$ for $18 \mathrm{hrs}$. The reaction was then cooled to $20^{\circ} \mathrm{C}$ and poured into water $(60 \mathrm{ml})$. The aqueous was extracted with ethyl acetate $(3 \times 40 \mathrm{ml})$ and the combined organic layers were dried over anhydrous sodium sulfate, filtered and concentrated. The residue was purified via silica gel chromatography (petroleum ether : ethyl acetate.; Gradient $0 \%$ to 33\% ethyl acetate) to afford desired product as a yellow solid. Yield: $250 \mathrm{mg}, 1.14 \mathrm{mmol}, 12.9 \%)$. Chemical Formula: C12H16N2O2, LCMS(ESI) $\mathrm{m} / \mathrm{z}$ : $[\mathrm{M}+\mathrm{H}]$ calcd: 220.1 ; found: 220.9 .

Step 2: Synthesis of 2-(1-(pyridin-2-yl)azetidin-3-yl)acetic acid (S9) 
To a round bottomed flask was added $\mathbf{S 8}$ (250 $\mathrm{mg}, 1.14 \mathrm{mmol})$, lithium hydroxide $(70.7 \mathrm{mg}, 2.95 \mathrm{mmol})$, tetrahydrofuran $(9 \mathrm{ml})$ and water $(3 \mathrm{ml})$. Reaction was stirred at $20^{\circ} \mathrm{C}$ for $3 \mathrm{hrs}$. The $\mathrm{pH}$ of the reaction was then adjusted to 7 with $1 \mathrm{M}$ aqueous $\mathrm{HCl}$. $50 \mathrm{ml}$ ethyl acetate was added and reaction dried over anhydrous sodium sulfate. The solids were filtered and filtrate concentrated to give desired as a yellow solid. Yield: 200mg, $1.04 \mathrm{mmol}$, 91\%.

Synthesis of 2-(1-phenylazetidin-3-yl)acetic acid (S11)

Step 1: Synthesis of ethyl 2-(1-phenylazetidin-3-yl)acetate (S10)

A mixture of bromobenzene (1.27 g, $6.22 \mathrm{mmol})$, S3b (1.60 g, $6.22 \mathrm{mmol})$, Xantphos (360 $\mathrm{mg}, 0.622 \mathrm{mmol})$, $\mathrm{Pd}_{2}(\mathrm{dba})_{3}(285 \mathrm{mg}, 0.311 \mathrm{mmol})$ and cesium carbonate $(8.1 \mathrm{~g}, 24.9 \mathrm{mmol})$ in anhydrous toluene $(40 \mathrm{~mL})$ was heated at $100^{\circ} \mathrm{C}$ with stirring under $\mathrm{N}_{2}$ atmosphere for 18 hours. The reaction mixture was poured into water $(50 \mathrm{ml})$ and extracted with ethyl acetate $(3 \times 50 \mathrm{ml})$. The combined organics were then washed with water $(60 \mathrm{ml})$ and brine $(60 \mathrm{ml})$ and dried over anhydrous sodium sulfate. The solvent was then removed in vacuo and the residue was purified via silica gel chromatography (petroleum ether : ethyl acetate $=3: 1)$ to give the product as a yellow oil. Yield: $800 \mathrm{mg}, 3.65 \mathrm{mmol}, 58.6 \%$. ${ }^{1} \mathrm{H} \mathrm{NMR}(400 \mathrm{MHz}$, $\left.\mathrm{CDCl}_{3}\right)$ 6 7.17-7.25 (m, 2H), 6.69-6.82 (m, $\left.1 \mathrm{H}\right), 6.45(\mathrm{~d}, J=7.53 \mathrm{~Hz}, 2 \mathrm{H}), 4.12-4.23(\mathrm{~m}, 2 \mathrm{H}), 3.99-4.11(\mathrm{~m}, 2 \mathrm{H})$, $3.56(\mathrm{dd}, J=5.77,7.28 \mathrm{~Hz}, 2 \mathrm{H}), 3.00-3.16(\mathrm{~m}, 1 \mathrm{H}), 2.70(\mathrm{~d}, J=8.03 \mathrm{~Hz}, 2 \mathrm{H}), 1.19-1.33(\mathrm{~m}, 3 \mathrm{H})$.

Step 2: Synthesis of 2-(1-phenylazetidin-3-yl)acetic acid (S11)

To a solution of $\mathbf{S 1 0}(800 \mathrm{mg}, 3.10 \mathrm{mmol})$ in tetrahydrofuran/water $(15 \mathrm{~mL} / 4 \mathrm{~mL})$ was added lithium hydroxide $(186 \mathrm{mg}, 7.75 \mathrm{mmol})$ at $20^{\circ} \mathrm{C}$ for $2 \mathrm{hrs}$ then at $45^{\circ} \mathrm{C}$ for $2 \mathrm{hrs}$. The reaction mixture was adjusted to $\mathrm{pH} \sim 7$ with $12 \mathrm{M} \mathrm{HCl}$. Tetrahydrofuran $(60 \mathrm{ml})$ was added and solution dried with anhydrous sodium sulfate. The solids were filtered off and washed with dichloromethane:methanol (10:1, 50ml). The fitrate was concentrated to give the desired compound which was used for the next step without purification. Yield: $400 \mathrm{mg}$, crude, contains salts.

\section{Synthesis of 2-(1-(4-methoxyphenyl)azetidin-3-yl)acetic acid (S13)}

Step 1: Synthesis of ethyl 2-(1-(4-methoxyphenyl)azetidin-3-yl)acetate (S12)

To a solution of $\mathbf{S} 3 \mathbf{b}(250 \mathrm{mg}, 1.04 \mathrm{mmol})$ in dioxane $(10 \mathrm{~mL})$ was added 4-bromoanisole $(245 \mathrm{mg}, 1.04$ $\mathrm{mmol})$, Xphos (24.9mg, $0.0522 \mathrm{mmol}), \mathrm{Pd}_{2}(\mathrm{dba})_{3}(47.8 \mathrm{mg}, 0.0522 \mathrm{mmol}$ ) and cesium carbonate $(1.7 \mathrm{~g}$, $5.22 \mathrm{mmol})$. The reaction was bubbled with nitrogen $(30 \mathrm{sec})$ and stirred at $100{ }^{\circ} \mathrm{C}$ for 16 hours. The reaction was cooled to room temperature and filtered. Filtrate concentrated and purified via silica gel chromatography (Petroleum ether: Ethyl Acetate, gradient 0-20\%) to provide title compound as a yellow oil. Yield: $210 \mathrm{mg}, 0.842 \mathrm{mmol}, 80.6 \%$. Chemical Formula: C14H19NO3, LCMS (ESI) m/z: [M+H] calcd: 249.1; found: 249.9 .

Step 2: Synthesis of 2-(1-(4-methoxyphenyl)azetidin-3-yl)acetic acid (S13)

A suspension of $\mathbf{S 1 2}(100 \mathrm{mg}, 0.4011 \mathrm{mmol})$ and lithium hydroxide monohydrate $(67.3 \mathrm{mg}, 1.60 \mathrm{mmol})$ in methanol $(2 \mathrm{~mL})$ and water $(1 \mathrm{~mL})$ was stirred at $60^{\circ} \mathrm{C}$ for $18 \mathrm{hrs}$. The reaction was concentrated in vacuo and the $\mathrm{pH}$ of the residue was adjusted to a $\mathrm{pH}$ of 6 with $1 \mathrm{~N}$ aqueous hydrochloric acid. The reaction was 
lyophilized to provide the title compound, which was used without further purification. Yield: $88.7 \mathrm{mg}$, $0.401 \mathrm{mmol}$, 99.9\%. Chemical Formula: C12H15NO3, LCMS (ESI) m/z: [M+H] calcd: 221.1; found: 221.9.

Synthesis of 2-(1-(4-cyanophenyl)azetidin-3-yl)acetic acid (S15)

Step1: Synthesis of ethyl 2-(1-(4-cyanophenyl)azetidin-3-yl)acetate (S14)

To a solution of $\mathbf{S} 3 \mathbf{b}$ (300 mg, $1.25 \mathrm{mmol})$ in dioxane $(10 \mathrm{~mL})$ was added 4-iodobenzonitrile $(345 \mathrm{mg}, 1.50$ $\mathrm{mmol})$, Xphos (59.8mg, $0.125 \mathrm{mmol}), \mathrm{Pd}_{2}(\mathrm{dba})_{3}(115 \mathrm{mg}, 0.125 \mathrm{mmol})$ and cesium carbonate $(1.23 \mathrm{~g}, 3.76$ $\mathrm{mmol})$. The reaction was bubbled with nitrogen $(120 \mathrm{sec})$ and stirred at $100^{\circ} \mathrm{C}$ for 16 hours. The reaction was diluted with water $(20 \mathrm{~mL})$ and extracted with ethyl acetate $(2 \times 25 \mathrm{~mL})$. The organic layers were combined, dried over anhydrous sodium sulfate, filtered and concentrated. The residue was purified via silica gel chromatography (Petroleum ether/Ethyl aceate, 3:1 isocratic) to afford title compound as a yellow oil. Yield: $230 \mathrm{mg}, 0.942 \mathrm{mmol}, 75.1 \%$. Chemical Formula: C14H16N2O2, LCMS (ESI) m/z: [M+H] calcd: 244.1 ; found: 244.9 .

Step 2: Synthesis of 2-(1-(4-cyanophenyl)azetidin-3-yl)acetic acid (S15)

A suspension of $\mathbf{S 1 4}(120 \mathrm{mg}, 0.491 \mathrm{mmol})$ and lithium hydroxide monohydrate $(61.8 \mathrm{mg}, 1.47 \mathrm{mmol})$ in methanol $(4 \mathrm{~mL})$ and water $(2 \mathrm{~mL})$ was stirred at $10^{\circ} \mathrm{C}$ for $16 \mathrm{hrs}$. The reaction was concentrated to $1 / 3$ volume and extracted with ethyl acetate $(3 \times 10 \mathrm{~mL})$. The aqueous was collected and adjusted to $\mathrm{pH}$ 5-6 with $1 \mathrm{~N}$ aqueous hydrochloric acid. The aqueous layer was then lyophilized to provide title compound as a white solid which was used without further purification. Yield: $90 \mathrm{mg}, 0.416 \mathrm{mmol}, 85 \%$. Chemical Formula: C12H12N2O2, LCMS (ESI) $m / z$ : [M+H] calcd: 216.1; found: 216.9 .

Synthesis of (2-6)

$\mathrm{Me}_{2} \mathrm{NH}_{2} \mathrm{Cl}, \mathrm{EDCl}$, HOAt

DIPEA, DMF, $45-70{ }^{\circ} \mathrm{C}$

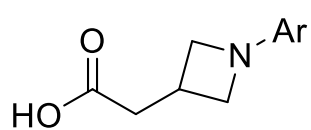

S7,S9.S11,S13,S15

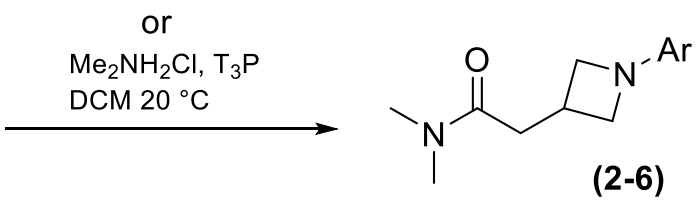

$$
\begin{aligned}
\mathrm{Ar}= & 4-\text { pyridine }(2) \\
& \text { 2-pyridine (3) } \\
& \text { phenyl (4) } \\
& \text { 4-methoxyphenyl (5) } \\
& \text { 4-cyanophenyl (6) }
\end{aligned}
$$

Synthesis of N,N-dimethyl-2-(1-(pyridin-4-yl)azetidin-3-yl)acetamide (2)

To a solution of $\mathbf{S 7}(60.0 \mathrm{mg}, 0.31 \mathrm{mmol})$ in dimethylformamide $(3 \mathrm{~mL})$ was added EDC-HCl $(71.8 \mathrm{mg}, 0.375$ $\mathrm{mmol}$ ) and DIPEA (121 mg, $0.163 \mathrm{mmol}$ ) followed by HOAt $(51 \mathrm{mg}, 0.375 \mathrm{mmol})$. The mixture was stirred 
at $10 \mathrm{C}$ for $10 \mathrm{~min}$. Dimethylamine hydrochloride $(76.4 \mathrm{mg}, 0.936 \mathrm{mmol})$ was added and the mixture was stirred at $60 \mathrm{C}$ for 8 hours. The reaction was concentrated and purified via C-18 chromatography (water:acetonitrile, 0-20\% gradient.). The isolated material was evaporated via lyophilization. The lyophilized material was purified by preparative TLC $(\mathrm{MeOH} / \mathrm{CH} 2 \mathrm{Cl} 2=1 / 6,0.5 \%$ of NH3. $\mathrm{H} 2 \mathrm{O})$ to give title compound as a white gum. Yield: $49.7 \mathrm{mg}, 0.226 \mathrm{mmol}, 73 \% .{ }^{1} \mathrm{H}$ NMR (CHLOROFORM-d, $\left.400 \mathrm{MHz}\right) \delta 8.16$ $(\mathrm{d}, 2 \mathrm{H}, J=6.4 \mathrm{~Hz}), 6.26(\mathrm{~d}, 2 \mathrm{H}, \mathrm{J}=6.4 \mathrm{~Hz}), 4.24(\mathrm{t}, 2 \mathrm{H}, J=8.3 \mathrm{~Hz}), 3.69(\mathrm{dd}, 2 \mathrm{H}, J=5.6,8.6 \mathrm{~Hz}), 3.2-3.3(\mathrm{~m}, 1 \mathrm{H})$, $3.03(\mathrm{~s}, 3 \mathrm{H}), 2.97(\mathrm{~s}, 3 \mathrm{H}), 2.75(\mathrm{~d}, 2 \mathrm{H}, \mathrm{J}=7.3 \mathrm{~Hz}$ ). Chemical Formula: C12H17N3O, LCMS (ESI) $\mathrm{m} / \mathrm{z}$ : [M+H] calcd: 219.1 ; found: 220.2 .

\section{Synthesis of N,N-dimethyl-2-(1-(pyridin-2-yl)azetidin-3-yl)acetamide (3)}

To a solution of $\mathbf{S 9}(60.0 \mathrm{mg}, 0.31 \mathrm{mmol})$ in dimethylformamide $(3 \mathrm{~mL})$ was added EDC- $\mathrm{HCl}(71.8 \mathrm{mg}, 0.375$ $\mathrm{mmol}$ ) followed by HOAt $(51 \mathrm{mg}, 0.375 \mathrm{mmol})$. The mixture was stirred at $10 \mathrm{C}$ for $10 \mathrm{~min}$. Dimethylamine hydrochloride $(76.4 \mathrm{mg}, 0.936 \mathrm{mmol})$ and DIPEA (121 $\mathrm{mg}, 0.163 \mathrm{mmol})$ was added and the mixture was stirred at $70 \mathrm{C}$ for 7 hours. The reaction was poured into water $(10 \mathrm{~mL})$ and extracted with ethyl acetate $(25 \mathrm{~mL})$. The organics were washed with brine $(15 \mathrm{~mL} \times 3)$, dried over anhydrous sodium sulfate, filtered and concentrated. The residue was purified via reversed phase HPLC to provide desired compound (Column: Agela Durashell C18 150*25, $5 \mu \mathrm{m}$; Mobile phase A: water containing $0.05 \%$ ammonium hydroxide (v/v); Mobile phase B: acetonitrile; Gradient: $13 \%$ to $33 \% \mathrm{~B}$ ). Provides title compound as white solid. Yield: $20.8 \mathrm{mg}, 0.095 \mathrm{mmol}, 30.4 \% .{ }^{1} \mathrm{H}$ NMR (CHLOROFORM-d, $400 \mathrm{MHz}$ ) $\delta 8.14$ (dd, $1 \mathrm{H}, \mathrm{J}=1.0,5.0$ $\mathrm{Hz}$ ), 7.43 (ddd, $1 \mathrm{H}, J=1.8,6.9,8.4 \mathrm{~Hz}$ ), 6.58 (dd, $1 \mathrm{H}, J=5.5,6.5 \mathrm{~Hz}), 6.26$ (d, $1 \mathrm{H}, J=8.5 \mathrm{~Hz}), 4.25$ (t, $2 \mathrm{H}, J=7.8$ $\mathrm{Hz}), 3.69(\mathrm{dd}, 2 \mathrm{H}, J=5.5,8.0 \mathrm{~Hz}), 3.1-3.2(\mathrm{~m}, 1 \mathrm{H}), 3.03(\mathrm{~s}, 3 \mathrm{H}), 2.96(\mathrm{~s}, 3 \mathrm{H}), 2.74(\mathrm{~d}, 2 \mathrm{H}, J=8.0 \mathrm{~Hz})$. Chemical Formula: C12H17N30, LCMS(ESI) $\mathrm{m} / \mathrm{z}:[\mathrm{M}+\mathrm{H}]$ calcd: 219.1; found: 220.2.

\section{Synthesis of N,N-dimethyl-2-(1-phenylazetidin-3-yl)acetamide (4)}

To a solution of $\mathbf{S 1 1}(70.0 \mathrm{mg}, 0.37 \mathrm{mmol})$ in dichloromethane $(5 \mathrm{~mL})$ was added dimethylamine hydrochloride $(51.9 \mathrm{mg}, 0.439 \mathrm{mmol})$ and triethylamine $(370 \mathrm{mg}, 3.66 \mathrm{mmol})$. Propanephosphonic acid anhydride ( $582 \mathrm{mg}, 0.915 \mathrm{mmol}, 50 \%$ solution in ethyl acetate) was added and the mixture stirred at 20 ${ }^{\circ} \mathrm{C}$ for $16 \mathrm{hrs}$. The reaction mixture was concentrated and purified via reversed phase HPLC to provide desired compound (Column: Agela Durashell C18 150*25, $5 \mu \mathrm{m}$; Mobile phase A: water containing 0.05\% ammonium hydroxide (v/v); Mobile phase B: acetonitrile; Gradient: $26 \%$ to $46 \% \mathrm{~B})$ to provide title compound. Yield: $33.49 \mathrm{mg}, 0.153 \mathrm{mmol}, 42 \%$. ${ }^{1} \mathrm{H}$ NMR (CHLOROFORM-d, $\left.400 \mathrm{MHz}\right) \delta 7.2-7.2(\mathrm{~m}, 2 \mathrm{H}$ ), $6.73(\mathrm{t}, 1 \mathrm{H}, J=7.3 \mathrm{~Hz}), 6.45(\mathrm{~d}, 2 \mathrm{H}, J=7.5 \mathrm{~Hz}), 4.10(\mathrm{t}, 2 \mathrm{H}, J=7.5 \mathrm{~Hz}), 3.54(\mathrm{dd}, 2 \mathrm{H}, J=5.5,7.5 \mathrm{~Hz}), 3.1-3.2(\mathrm{~m}$, $1 \mathrm{H}), 3.02(\mathrm{~s}, 3 \mathrm{H}), 2.97(\mathrm{~s}, 3 \mathrm{H}), 2.73(\mathrm{~d}, 2 \mathrm{H}, \mathrm{J}=7.5 \mathrm{~Hz})$. Chemical Formula: C13H18N2O, LCMS (ESI) $\mathrm{m} / \mathrm{z}$ : $[\mathrm{M}+\mathrm{H}]$ calcd: 218.1 ; found: 219.3 .

\section{Synthesis of 2-(1-(4-methoxyphenyl)azetidin-3-yl)-N, N-dimethylacetamide (5)}

To a solution of $\mathbf{S 1 3}(190 \mathrm{mg}, 0.859)$ in dimethylformamide $(5 \mathrm{~mL})$ was added $\mathrm{EDC}-\mathrm{HCl}(198 \mathrm{mg}, 1.03 \mathrm{mmol})$ followed by HOAt $(140 \mathrm{mg}, 1.03 \mathrm{mmol})$. The mixture was stirred at 10C for $30 \mathrm{~min}$. Dimethylamine 
hydrochloride (140 mg, $1.72 \mathrm{mmol}$ ) and DIPEA (444 mg, $3.43 \mathrm{mmol}$ ) was added and the mixture was stirred at $45{ }^{\circ} \mathrm{C}$ for 18 hours. The reaction was filtered and concentrated. Residue purified via reversed phase HPLC to provide desired compound (Column: Agela Durashell C18 150*25, $5 \mu \mathrm{m}$; Mobile phase A: water containing $0.05 \%$ ammonium hydroxide (v/v); Mobile phase B: acetonitrile; Gradient: $22 \%$ to $42 \%$ B). Provides title compound as white solid. Yield: $31.5 \mathrm{mg}, 0.127 \mathrm{mmol}, 14.8 \%$. ${ }^{1} \mathrm{H}$ NMR (METHANOL-d $400 \mathrm{MHz}$ ) $\delta 6.79$ (d, 2H, J=9.0 Hz), 6.47 (d, $2 \mathrm{H}, J=8.5 \mathrm{~Hz}$ ), $3.96(\mathrm{t}, 2 \mathrm{H}, J=7.5 \mathrm{~Hz}), 3.71(\mathrm{~s}, 3 \mathrm{H}), 3.44$ (dd, $2 \mathrm{H}$, $J=6.0,7.0 \mathrm{~Hz}), 3.05(\mathrm{~s}, 3 \mathrm{H}), 3.0-3.0(\mathrm{~m}, 1 \mathrm{H}), 2.93(\mathrm{~s}, 3 \mathrm{H}), 2.77(\mathrm{~d}, 2 \mathrm{H}, J=7.5 \mathrm{~Hz})$. Chemical Formula: C14H2ON2O2, LCMS (ESI) m/z: [M+H] calcd: 248.2; found: 249.3.

\section{Synthesis of 2-(1-(4-cyanophenyl)azetidin-3-yl)-N,N-dimethylacetamide (6)}

To a solution of $\mathbf{S 1 5}(100 \mathrm{mg}, 0.462)$ in dimethylformamide $(5 \mathrm{~mL})$ was added EDC-HCl $(106 \mathrm{mg}, 0.555$ mmol) followed by HOAt $(75.5 \mathrm{mg}, 0.555 \mathrm{mmol})$. The mixture was stirred at $10 \mathrm{C}$ for $30 \mathrm{~min}$.

Dimethylamine hydrochloride (113 mg, $1.39 \mathrm{mmol}$ ) and DIPEA (179 mg, $1.39 \mathrm{mmol}$ ) was added and the mixture was stirred at $60{ }^{\circ} \mathrm{C}$ for 31 hours. The reaction mixture was cooled to room temperature and diluted with water $(20 \mathrm{~mL})$ and extracted with ethyl acetate $(3 \times 20 \mathrm{~mL})$. The organic layers were combined and washed with brine $(30 \mathrm{~mL})$, dried over anhydrous sodium sulfate, filtered and concentrated. The residue was purified via reversed phase chromatography (Water/Acetonitrile, 85:15 isocratic) to afford crude product as a yellow solid. The residue was purified via reversed phase HPLC to provide desired compound (Column: Agela Durashell C18 150*25, $5 \mu \mathrm{m}$; Mobile phase A: water containing $0.05 \%$ ammonium hydroxide (v/v); Mobile phase B: acetonitrile; Gradient: $25 \%$ to $45 \%$ B) to provide title compound as a white solid. Yield: $38.5 \mathrm{mg}, 0.158 \mathrm{mmol}, 34.3 \%$. ${ }^{1} \mathrm{H}$ NMR (DMSO- $\mathrm{d}_{6}, 400$ $\mathrm{MHz}$ ) 6 7.4-7.6 (m, 2H), 6.4-6.5 (m, 2H), 4.02-4.07 (m, 2H), 3.55 (dd, 2H, J=5.6, 8.1 Hz), 2.92-3.03 (m, 1H), $2.94(\mathrm{~s}, 3 \mathrm{H}), 2.80(\mathrm{~s}, 3 \mathrm{H}), 2.72(\mathrm{~d}, 2 \mathrm{H}, \mathrm{J}=7.8 \mathrm{~Hz}$ ). Chemical Formula: C14H17N3O, LCMS (ESI) $\mathrm{m} / \mathrm{z}$ : [M+H] calcd: 243.1; found: 243.9 .

Synthesis of $(1,10,11,12,13)$ 


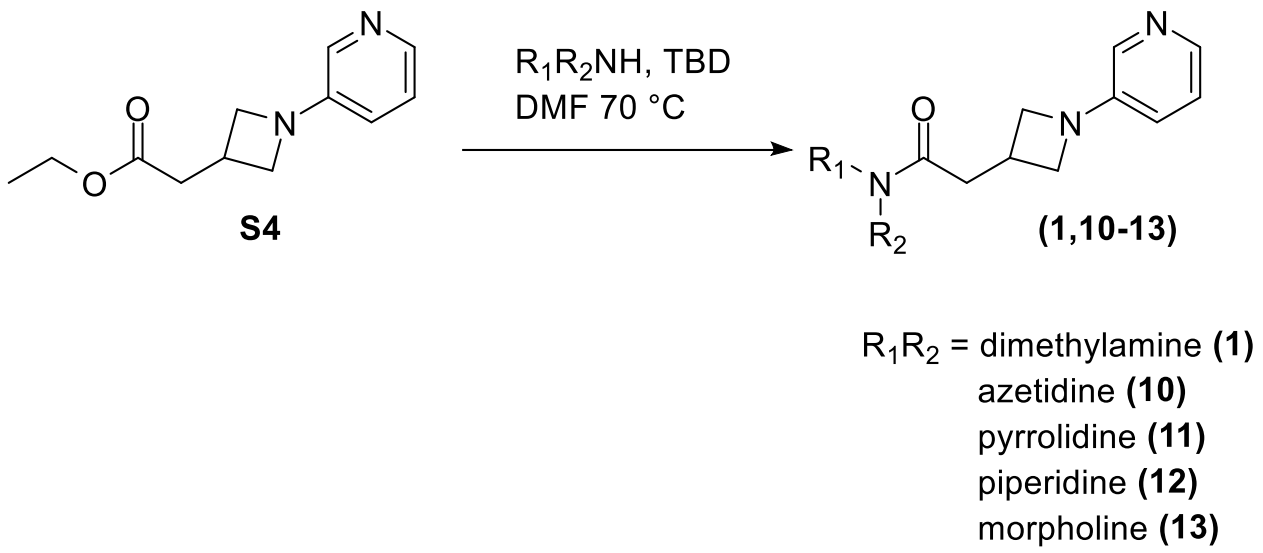

Synthesis of N,N-dimethyl-2-(1-(pyridin-3-yl)azetidin-3-yl)acetamide (1)

To a vial was added $\mathbf{S 4}$ (55 mg, $0.25 \mathrm{mmol}$ ) and dimethylamine ( $500 \mathrm{mg}, 10 \mathrm{mmol}, 5.0 \mathrm{~mL}, 2.0 \mathrm{M}$ in THF). Triazabicyclo[4.4.0]Dec-5-ene (104 $\mathrm{mg}, 0.749 \mathrm{mmol})$ was added and the reaction was heated at 70C 16 hrs. The reaction was cooled to $20 \mathrm{C}$ and the reaction was absorbed on silica g el and purified via silica gel chromatography (Ethyl Acetate w/1\% TEA modifier:Methanol gradient 0-10\%). Provides title compound: Yield: $46 \mathrm{mg}, 0.21 \mathrm{mmol}, 84 \%$. ${ }^{1} \mathrm{H}$ NMR (CHLOROFORM-d, $\left.400 \mathrm{MHz}\right) \delta 8.00$ (dd, $1 \mathrm{H}, J=1.2,4.7 \mathrm{~Hz}$ ), 7.86 (d, $1 \mathrm{H}, J=2.7 \mathrm{~Hz}), 7.10(\mathrm{dd}, 1 \mathrm{H}, J=4.7,8.2 \mathrm{~Hz}), 6.7-6.7(\mathrm{~m}, 1 \mathrm{H}), 4.16(\mathrm{t}, 2 \mathrm{H}, J=7.6 \mathrm{~Hz}), 3.60(\mathrm{dd}, 2 \mathrm{H}, J=5.7,7.2$ $\mathrm{Hz}), 3.1-3.3(\mathrm{~m}, 1 \mathrm{H}), 3.03(\mathrm{~s}, 3 \mathrm{H}), 2.97(\mathrm{~s}, 3 \mathrm{H}), 2.75(\mathrm{~d}, 2 \mathrm{H}, \mathrm{J}=7.8 \mathrm{~Hz})$. Chemical Formula: C12H17N3O, LCMS (ESI) $\mathrm{m} / \mathrm{z}:[\mathrm{M}+\mathrm{H}]$ calcd: 219.1 ; found: 220.5 .

Synthesis 1-(azetidin-1-yl)-2-(1-(pyridin-3-yl)azetidin-3-yl)ethan-1-one (10)

A 1 dram vial was charged with azetidine $(23.1 \mathrm{mg}, 0.275 \mathrm{mmol}), \mathbf{S 4}(46 \mathrm{mg}, 0.210 \mathrm{mmol})$ and DMF $(0.7$ $\mathrm{mL}$ ). To this solution was added Triazabicyclo[4.4.0]Dec-5-ene $(58.1 \mathrm{mg}, 0.418 \mathrm{mmol})$. The reaction was heated to $70^{\circ} \mathrm{C}$ for 18 hours. After cooling to rt the solution was diluted with water (1.5 mL's) and DCM $(1 \mathrm{~mL})$. The phases were separated and the aqueous phase extracted with DCM $(1 \mathrm{~mL}, 2 \mathrm{x})$. The combined organics were washed with brine $(2 \mathrm{~mL}, 1 \mathrm{x})$, dried over sodium sulfate, filtered, and concentrated. Residue was subjected to silica gel chromatography (Dichloromethane/Methanol, $0-5 \%$ gradient) to provide title compound. Yield: $32 \mathrm{mg}, 0.138 \mathrm{mmol}, 66 \%$. $1 \mathrm{H} \mathrm{NMR} \mathrm{(400} \mathrm{MHz,} \mathrm{cdcl3)} \mathrm{Shift} 7.97$ (dd, J=1.56, $4.70 \mathrm{~Hz}, 1 \mathrm{H}$ ), 7.82 (d, J=2.74 Hz, 1H), 7.09 (dd, J=4.70, 8.22 Hz, 1H), 6.70 (ddd, J=1.17, 2.74, 8.22 Hz, 1H), 4.07-4.18 (m, $4 \mathrm{H}), 4.02(\mathrm{t}, \mathrm{J}=7.83 \mathrm{~Hz}, 2 \mathrm{H}), 3.58(\mathrm{dd}, \mathrm{J}=5.48,7.43 \mathrm{~Hz}, 2 \mathrm{H}), 3.08-3.20(\mathrm{~m}, \mathrm{~J}=7.80,7.80 \mathrm{~Hz}, 1 \mathrm{H})$, $2.46(\mathrm{~d}, \mathrm{~J}=7.83 \mathrm{~Hz}, 2 \mathrm{H}), 2.23-2.34(\mathrm{~m}, 2 \mathrm{H})$. Chemical Formula: C13H17N3O, LCMS (ESI) $\mathrm{m} / \mathrm{z}$ : [M+H] calcd: 231.1; found: 232.5 .

Synthesis 2-(1-(pyridin-3-yl)azetidin-3-yl)-1-(pyrrolidin-1-yl)ethan-1-one (11) 
A 1 dram vial was charged with pyrrolidine (16 $\mathrm{mg}, 0.225 \mathrm{mmol}), \mathbf{S} 4(46 \mathrm{mg}, 0.210 \mathrm{mmol})$ and DMF (0.7 $\mathrm{mL}$ ). To this solution was added Triazabicyclo[4.4.0]Dec-5-ene ( $56.9 \mathrm{mg}$ 's, $0.409 \mathrm{mmol}$ ). The reaction was heated to $70^{\circ} \mathrm{C}$ for 18 hours. After cooling to rt the solution was diluted with water $(1.5 \mathrm{~mL}$ 's) and DCM $(1 \mathrm{~mL})$. The phases were separated and the aqueous phase extracted with DCM $(1 \mathrm{~mL}, 2 \mathrm{x})$. The combined organics were washed with brine $(2 \mathrm{~mL}, 1 \mathrm{x})$, dried over sodium sulfate, filtered, and concentrated. Residue was subjected to silica gel chromatography (Dichloromethane/Methanol, $0-5 \%$ gradient) to provide title compound. Yield: $30 \mathrm{mg}, 0.122 \mathrm{mmol}, 60 \%$. $1 \mathrm{H} \mathrm{NMR} \mathrm{(400} \mathrm{MHz,} \mathrm{cdcl3)} \mathrm{Shift} 7.97$ (dd, J=1.17, $4.70 \mathrm{~Hz}, 1 \mathrm{H}), 7.83(\mathrm{~d}, \mathrm{~J}=2.74 \mathrm{~Hz}, 1 \mathrm{H}), 7.08(\mathrm{dd}, \mathrm{J}=4.70,8.22 \mathrm{~Hz}, 1 \mathrm{H}), 6.67-6.73(\mathrm{~m}, 1 \mathrm{H}), 4.13(\mathrm{t}, \mathrm{J}=7.63 \mathrm{~Hz}$, $2 \mathrm{H}), 3.59(\mathrm{dd}, \mathrm{J}=5.48,7.43 \mathrm{~Hz}, 2 \mathrm{H}), 3.45(\mathrm{t}, \mathrm{J}=6.85 \mathrm{~Hz}, 2 \mathrm{H}), 3.40(\mathrm{t}, \mathrm{J}=6.85 \mathrm{~Hz}, 2 \mathrm{H}), 3.12-3.26(\mathrm{~m}, 1 \mathrm{H}), 2.93-$ $3.03(\mathrm{~m}, 1 \mathrm{H}), 2.67(\mathrm{~d}, \mathrm{~J}=7.83 \mathrm{~Hz}, 2 \mathrm{H}), 1.91-2.02(\mathrm{~m}, 2 \mathrm{H}), 1.80-1.90(\mathrm{~m}, 2 \mathrm{H})$. Chemical Formula: C14H19N3O, LCMS (ESI) $m / z$ : [M+H] calcd: 245.1; found: 246.5 .

Synthesis 1-(piperidin-1-yl)-2-(1-(pyridin-3-yl)azetidin-3-yl)ethan-1-one (12)

A 1 dram vial was charged with piperidine $(12.8 \mathrm{mg}, 0.15 \mathrm{mmol}), \mathbf{S} 4(30 \mathrm{mg}, 0.140 \mathrm{mmol})$ and DMF $(0.3$ $\mathrm{mL}$ ). To this solution was added Triazabicyclo[4.4.0]Dec-5-ene $(37.9 \mathrm{mg}, 0.272 \mathrm{mmol})$. The reaction was heated to $70^{\circ} \mathrm{C}$ for 18 hours. After cooling to rt the solution was diluted with water (1.5 mL's) and DCM $(1 \mathrm{~mL})$. The phases were separated and the aqueous phase extracted with DCM $(1 \mathrm{~mL}, 2 \mathrm{x})$. The combined organics were washed with brine $(2 \mathrm{~mL}, 1 \mathrm{x})$, dried over sodium sulfate, filtered, and concentrated. Residue was subjected to silica gel chromatography (Dichloromethane/Methanol, $0-5 \%$ gradient) to provide title compound. Yield: $5 \mathrm{mg}, 0.019 \mathrm{mmol}, 10 \% 1 \mathrm{H} \mathrm{NMR} \mathrm{(400} \mathrm{MHz,} \mathrm{CDCl3)} \mathrm{Shift} 7.99$ (dd, J=1.17, $5.07 \mathrm{~Hz}, 1 \mathrm{H}$ ), 7.84 (d, J=2.73 Hz, 1H), 7.22 (dd, J=5.07, 8.20 Hz, 1H), 6.83 (ddd, J=1.37, 2.83, 8.29 Hz, 1H), $4.20(\mathrm{t}, \mathrm{J}=7.61 \mathrm{~Hz}, 2 \mathrm{H}), 3.62-3.66(\mathrm{~m}, \mathrm{~J}=5.46 \mathrm{~Hz}, 2 \mathrm{H}), 3.66(\mathrm{~s}, 1 \mathrm{H}), 3.55-3.60(\mathrm{~m}, 2 \mathrm{H}), 3.40-3.45(\mathrm{~m}, \mathrm{~J}=5.46$ $\mathrm{Hz}, 2 \mathrm{H}), 3.23(\mathrm{~s}, 1 \mathrm{H}), 2.76(\mathrm{~d}, \mathrm{~J}=7.81 \mathrm{~Hz}, 2 \mathrm{H}), 1.64-1.72(\mathrm{~m}, 2 \mathrm{H}), 1.53-1.63(\mathrm{~m}, 4 \mathrm{H})$. Chemical Formula: C15H21N3O, LCMS (ESI) $\mathrm{m} / \mathrm{z}$ : [M+H] calcd: 259.1; found: 260.5 .

Synthesis 1-morpholino-2-(1-(pyridin-3-yl)azetidin-3-yl)ethan-1-one (13)

A 1 dram vial was charged with morpholine $(23.9 \mathrm{mg}, 0.275 \mathrm{mmol}), \mathbf{S 4}(55 \mathrm{mg}, 0.250 \mathrm{mmol})$ and DMF (0.8 $\mathrm{mL})$. To this solution was added Triazabicyclo[4.4.0]Dec-5-ene $(69.5 \mathrm{mg}, 0.499 \mathrm{mmol})$. The reaction was heated to $70^{\circ} \mathrm{C}$ for 18 hours. After cooling to rt the solution was diluted with water ( $1.5 \mathrm{~mL}$ 's) and DCM $(1 \mathrm{~mL})$. The phases were separated and the aqueous phase extracted with DCM $(1 \mathrm{~mL}, 2 \mathrm{x})$. The combined organics were washed with brine $(2 \mathrm{~mL}, 1 \mathrm{x})$, dried over sodium sulfate, filtered, and concentrated. Residue was subjected to silica gel chromatography (Dichloromethane/Methanol, $0-5 \%$ gradient) to provide title compound. Yield: $27 \mathrm{mg}, 0.103 \mathrm{mmol}, 41 \%$. 1H NMR (400 MHz, cdcl3) Shift 7.95-8.01 (m, 1H), $7.83(\mathrm{~d}, \mathrm{~J}=2.35 \mathrm{~Hz}, 1 \mathrm{H}), 7.10$ (dd, J=4.70, $8.22 \mathrm{~Hz}, 1 \mathrm{H}), 6.71$ (ddd, J=1.17, 2.74, 8.22 Hz, 1H), 4.14 (t, J=7.63 $\mathrm{Hz}, 2 \mathrm{H}), 3.65-3.71(\mathrm{~m}, 3 \mathrm{H}), 3.58(\mathrm{dd}, \mathrm{J}=5.48,7.43 \mathrm{~Hz}, 5 \mathrm{H}), 3.43-3.49(\mathrm{~m}, 2 \mathrm{H}), 3.11-3.25(\mathrm{~m}, 1 \mathrm{H}), 2.70-2.76$ (m, 2H). Chemical Formula: C14H19N3O2, LCMS (ESI) m/z: [M+H] calcd: 261.2; found: 262.5. 
Synthesis of N,N-dimethyl-2-(1-(pyridin-3-yl)pyrrolidin-3-yl)acetamide (7)
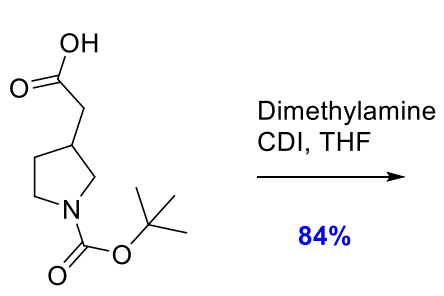

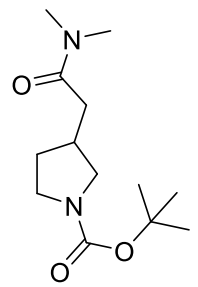

(S16)

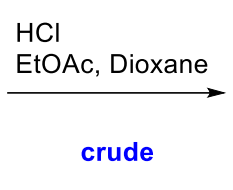

$(\mathbf{S} 17)$

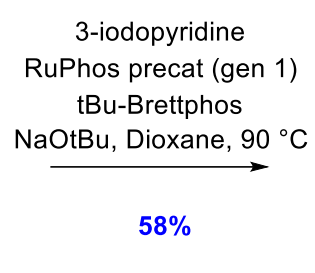

(7)

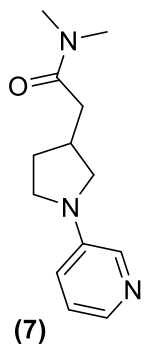

Step 1: Synthesis of tert-butyl 3-(2-(dimethylamino)-2-oxoethyl)pyrrolidine-1-carboxylate (S16)

A solution of 2-(1-(tert-butoxycarbonyl)pyrrolidin-3-yl)acetic acid (700 mg, $3.05 \mathrm{mmol}$ ) and CDI (545 mg, $3.36 \mathrm{mmol})$ in THF $(30 \mathrm{~mL}$ ) was stirred at room temperature for 1 hour. Dimethylamine (900 mg, $20 \mathrm{mmol}, 10 \mathrm{~mL}, 2 \mathrm{M}$ in THF) was added and the reaction was stirred at room temperature for 18 hours. The reaction was concentrated, diluted with $\mathrm{DCM}(50 \mathrm{~mL})$ and washed with $\mathrm{HCl}(3 \times 50 \mathrm{~mL}, 0.5 \mathrm{~N}$ aqueous). The organics were dried with anhydrous sodium sulfate, filtered and concentrated. The residue was purified via silica gel chromatography (DCM/MeOH, $0-20 \%$ gradient) to provide title compound as a yellow oil. Yield: $657 \mathrm{mg}, 2.56 \mathrm{mmol}, 84 \%$. ${ }^{1} \mathrm{H}$ NMR $\left(400 \mathrm{MHz}, \mathrm{CDCl}_{3}\right)$ 8 3.57-3.70 $(\mathrm{m}, 1 \mathrm{H}), 3.38-3.54(\mathrm{~m}, 1 \mathrm{H}), 3.25-3.38(\mathrm{~m}, 1 \mathrm{H}), 2.85-3.04(\mathrm{~m}$, $5 \mathrm{H}), 2.51-2.72(\mathrm{~m}, 1 \mathrm{H}), 2.26-2.50(\mathrm{~m}, 2 \mathrm{H}), 2.00-2.22(\mathrm{~m}, 1 \mathrm{H}), 1.50-1.64(\mathrm{~m}, 1 \mathrm{H}), 1.40-1.49(\mathrm{~m}, 9 \mathrm{H})$, (2 protons not observed). Chemical Formula: C14H19N3O2, GCMS m/z: calcd: 256.2; found: 257.1.

Step 2: Synthesis of N,N-dimethyl-2-(pyrrolidin-3-yl)acetamide hydrochloride salt (S17)

To a solution of $\mathbf{S 1 6}(657 \mathrm{mg}, 2.56 \mathrm{mmol})$ in EtOAc $(20 \mathrm{~mL})$ was added hydrochloric acid $(25.6 \mathrm{mmol}, 10$ $\mathrm{mL}, 4 \mathrm{~N}$ in dioxane). The reaction was stirred at room temperature for 18 hours. The solvent was removed and the sample dried under vacuum for 18 hours to provide title compounds as a clear oil. Yield: $530 \mathrm{mg}$, $2.74 \mathrm{mmol}, 107 \% .{ }^{1} \mathrm{H} \mathrm{NMR}(400 \mathrm{MHz}, \mathrm{DMSO})$ 8 8.77-9.18 (m, 2H), 3.28-3.40 (m, $\left.1 \mathrm{H}\right), 3.15-3.26(\mathrm{~m}, 1 \mathrm{H})$, 3.01-3.14 (m, 1H), $2.94(\mathrm{~s}, 2 \mathrm{H}), 2.81(\mathrm{~s}, 2 \mathrm{H}), 2.65-2.78(\mathrm{~m}, 1 \mathrm{H}), 2.52-2.58(\mathrm{~m}, 1 \mathrm{H}), 2.47-2.51(\mathrm{~m}, 1 \mathrm{H}$, partially obscured by solvent), 2.40-2.46 (m, 1H), $2.07(\mathrm{~m}, 1 \mathrm{H}), 1.45-1.59(\mathrm{~m}, 1 \mathrm{H}),(2$ protons not observed). Chemical Formula: C8H16N2O, LCMS (ESI) m/z: [M+H] calcd: 156.1; found: 157.3.

Step 3: Synthesis of N, N-dimethyl-2-(1-(pyridin-3-yl)pyrrolidin-3-yl)acetamide (7)

To a vial was added S17 (150 mg, $0.778 \mathrm{mmol}$ ), 3-iodopyridine (319 mg, $1.56 \mathrm{mmol}$ ), sodium tert-butoxide (187 mg, $1.95 \mathrm{mmol}$ ), Ruphos precatalyst (gen1) (38.2 mg, $0.046 \mathrm{mmol})$, tBuBrettPhos (22.6 mg, 0.046 $\mathrm{mmol})$. Dioxane $(4 \mathrm{~mL})$ was added and the vessel was purged $3 \times$ nitrogen. The reaction was heated at $90{ }^{\circ} \mathrm{C}$ for 18 hours. The reaction was cooled to room temperature, absorbed on silica gel and purified via silica gel chromatography (DCM/MeOH, 0-20\% gradient) to provide title compound. Yield: $105 \mathrm{mg}, 0.45$ mmol, 58\%. ${ }^{1} \mathrm{H}$ NMR $\left(400 \mathrm{MHz}, \mathrm{CDCl}_{3}\right) \delta 7.98(\mathrm{~d}, J=3.12 \mathrm{~Hz}, 1 \mathrm{H}), 7.93(\mathrm{dd}, J=1.17,4.68 \mathrm{~Hz}, 1 \mathrm{H}$ ), 7.10 (dd, 
$J=4.68,8.59 \mathrm{~Hz}, 1 \mathrm{H}), 6.81$ (ddd, J=1.17, 2.93, 8.39 Hz, 1H), 3.62 (dd, J=7.22, 9.17 Hz, 1H), 3.37-3.45 (m, $1 \mathrm{H}$ ), 3.28-3.37 (m, $1 \mathrm{H}), 3.02(\mathrm{~s}, 3 \mathrm{H}), 3.00(\mathrm{~m}, 1 \mathrm{H}), 2.98(\mathrm{~s}, 3 \mathrm{H}), 2.85$ (quind, $J=7.20,14.54 \mathrm{~Hz}, 1 \mathrm{H}), 2.43-2.57(\mathrm{~m}$, $2 \mathrm{H}), 2.25-2.36(\mathrm{~m}, 1 \mathrm{H}), 1.66-1.80(\mathrm{~m}, 1 \mathrm{H})$. Chemical Formula: C13H19N3O, LCMS (ESI) m/z: [M+H] calcd: 233.2; found: 234.5 .

\section{Synthesis of N,N-dimethyl-3-(1-(pyridin-3-yl)azetidin-3-yl)propenamide (8)}
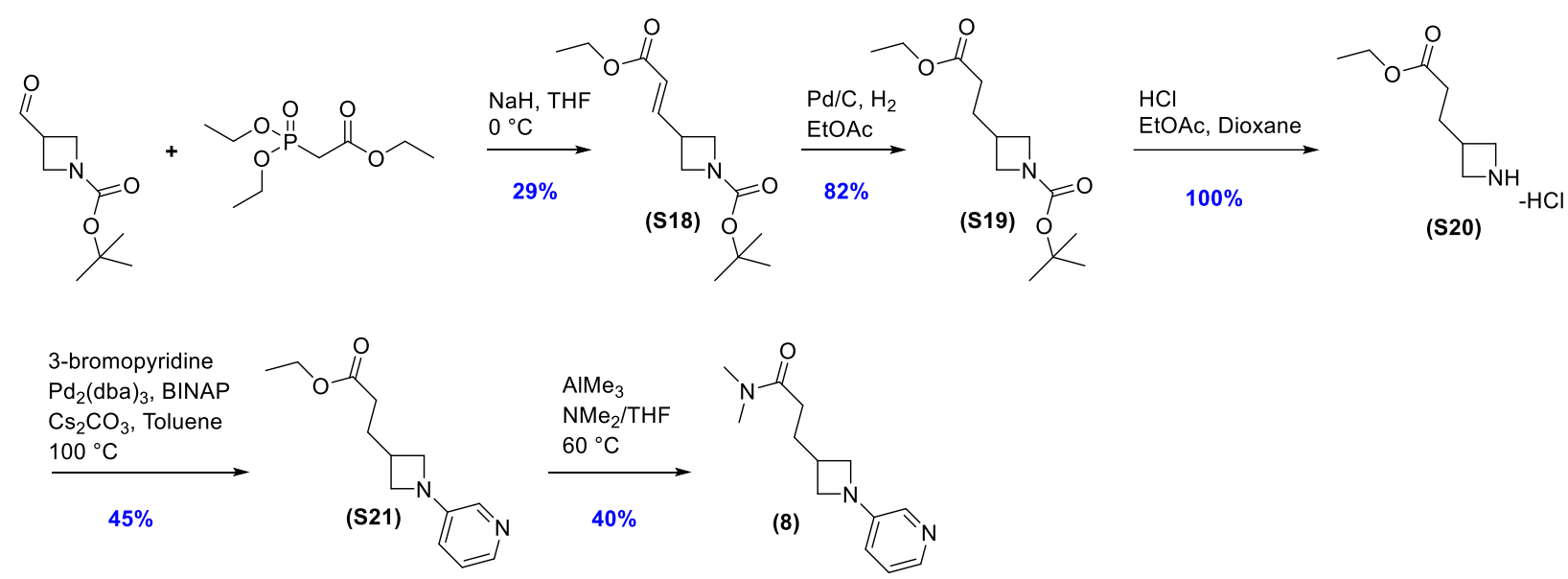

Step 1: Synthesis of tert-butyl(E)-3-(3-ethoxy-3-oxoprop-1-en-1-yl)azetidine-1-carboxylate (S18)

To a solution of ethyl-2-(diethoxyphosphoryl)acetate $(1.51 \mathrm{~g}, 6.75 \mathrm{mmol})$ in THF (20 $\mathrm{mL}$, anhydrous) at 0 ${ }^{\circ} \mathrm{C}$ was added sodium hydride $\left(432 \mathrm{mg}, 10.8 \mathrm{mmol}\right.$ ) portion wise. The reaction was stirred at $0{ }^{\circ} \mathrm{C}$ for 10 min at which point a solution of tert-butyl 3-formylazetidine-1-carboxylate $(1.0 \mathrm{~g}, 5.39 \mathrm{mmol})$ was added. The reaction was stirred at $0{ }^{\circ} \mathrm{C}$ for $30 \mathrm{~min}$. The reaction was quenched with saturated aqueous ammonium chloride $(50 \mathrm{~mL})$. The aqueous was washed with EtOAc $(2 \times 50 \mathrm{~mL})$, the combined organic layers washed with brine $(2 \times 25 \mathrm{~mL})$ and dried over sodium sulfate. The residue was purified via silica gel chromatography (petroleum ether/EtOAc, 0-30\% gradient). Yield: $400 \mathrm{mg}, 1.57 \mathrm{mmol}, 29 \% .{ }^{1} \mathrm{H}$ NMR (400 $\left.\mathrm{MHz}_{2} \mathrm{CDCl}_{3}\right) \delta 7.08(\mathrm{dd}, J=8.14,15.63 \mathrm{~Hz}, 1 \mathrm{H}), 5.81-5.92(\mathrm{~m}, 1 \mathrm{H}), 4.17-4.25(\mathrm{~m}, 2 \mathrm{H}), 4.08-4.17(\mathrm{~m}, 2 \mathrm{H}), 3.80$ (dd, $J=5.94,8.58 \mathrm{~Hz}, 2 \mathrm{H}), 3.27-3.40(\mathrm{~m}, 1 \mathrm{H}), 1.41-1.46(\mathrm{~m}, 9 \mathrm{H}), 1.29(\mathrm{t}, J=7.26 \mathrm{~Hz}, 3 \mathrm{H})$

Step 2: Synthesis of tert-butyl3-(3-ethoxy-3-oxopropyl)azetidine-1-carboxylate (S19)

To a solution of $\mathbf{S 1 8}(400 \mathrm{mg}, 1.57 \mathrm{mmol})$ in EtOAc $(50 \mathrm{~mL})$ was added $10 \%$ palladium on carbon $(500 \mathrm{mg})$. The mixture was stirred under an atmos phere of hydrogen ( $25 \mathrm{psi}$ ) for 18 hours. The reaction was filtered through celite and the filtrate concentrated to give the title compound. Yield: $330 \mathrm{mg}, 1.28 \mathrm{mmol}, 82 \%$. ${ }^{1} \mathrm{H} \mathrm{NMR}\left(400 \mathrm{MHz}, \mathrm{CDCl}_{3}\right) \delta 4.13(\mathrm{q}, J=7.04 \mathrm{~Hz}, 2 \mathrm{H}), 4.00(\mathrm{t}, J=8.36 \mathrm{~Hz}, 2 \mathrm{H}), 3.55(\mathrm{dd}, J=5.50,8.58 \mathrm{~Hz}, 2 \mathrm{H})$, $2.46-2.58(\mathrm{~m}, 1 \mathrm{H}), 2.22-2.30(\mathrm{~m}, 2 \mathrm{H}), 1.91(\mathrm{q}, J=7.78 \mathrm{~Hz}, 2 \mathrm{H}), 1.40-1.48(\mathrm{~m}, 9 \mathrm{H}), 1.26(\mathrm{t}, J=7.04 \mathrm{~Hz}, 3 \mathrm{H})$.

Step 3: Synthesis of ethyl 3-(azetidin-3-yl)propanoate hydrochloride salt (S20)

To a solution of $\mathbf{S 1 9}(1000 \mathrm{mg}, 3.89 \mathrm{mmol})$ in EtOAc $(5 \mathrm{~mL})$ was added hydrochloric acid $(80 \mathrm{mmol}, 20 \mathrm{~mL}$, $4 \mathrm{~N}$ in dioxane). The reaction was stirred at $26^{\circ} \mathrm{C}$ for 1 hour and then concentrated in vacuo to give title compound as a colorless gum utilized without further purification. Yield: $753 \mathrm{mg}, 3.89 \mathrm{mmol}, 100 \%$. 
A mixture of $\mathbf{S 2 0}(753 \mathrm{mg}, 3.89 \mathrm{mmol}), 3$-bromopyridine $(650 \mathrm{mg}, 4.11 \mathrm{mmol})$, cesium carbonate $(5.07 \mathrm{~g}$, $15.5 \mathrm{mmol}), \mathrm{Pd}_{2}(\mathrm{dba})_{3}(178 \mathrm{mg}, 0.194 \mathrm{mmol})$ and BINAP $(242 \mathrm{mg}, 0.39 \mathrm{mmol})$ in toluene $(45 \mathrm{~mL}$, anhydrous) was placed under a blanket of nitrogen and heated at $100^{\circ} \mathrm{C}$ for 18 hours. The reaction was cooled to RT and filtered through celite. The filtrate was concentrated and the residue purified via silica gel chromatography (petroleum ether/EtOAc; 0-35\% gradient) to provide title compound as a yellow oil. Yield: $410 \mathrm{mg}, 1.75 \mathrm{mmol}, 45 \% .{ }^{1} \mathrm{H}$ NMR $\left(400 \mathrm{MHz}, \mathrm{CDCl}_{3}\right) \delta 7.99$ (dd, J=1.25, $\left.4.77 \mathrm{~Hz}, 1 \mathrm{H}\right), 7.84$ (d, $J=3.01$ $\mathrm{Hz}, 1 \mathrm{H}), 7.06-7.12(\mathrm{~m}, 1 \mathrm{H}), 6.70$ (ddd, $J=1.51,2.89,8.16 \mathrm{~Hz}, 1 \mathrm{H}), 4.14(\mathrm{q}, J=7.03 \mathrm{~Hz}, 2 \mathrm{H}), 4.03(\mathrm{t}, J=7.53 \mathrm{~Hz}$, $2 \mathrm{H}), 3.54(\mathrm{dd}, J=5.52,7.03 \mathrm{~Hz}, 2 \mathrm{H}), 2.73-2.85(\mathrm{~m}, 1 \mathrm{H}), 2.33(\mathrm{t}, J=7.53 \mathrm{~Hz}, 2 \mathrm{H}), 2.00(\mathrm{q}, J=7.53 \mathrm{~Hz}, 2 \mathrm{H}), 1.24-$ $1.30(\mathrm{~m}, 3 \mathrm{H})$

Step 5: Synthesis of N,N-dimethyl-3-(1-(pyridin-3-yl)azetidin-3-yl)propenamide (8)

Dimethylamine (10 mL, $20 \mathrm{mmol}, 2 \mathrm{M}$ in THF) was added to $\mathbf{S 2 1}$ ( $250 \mathrm{mg}, 1.07 \mathrm{mmol})$. Triemethylaluminum $\left(2.13 \mathrm{~mL}, 4.27 \mathrm{mmol}, 2 \mathrm{M}\right.$ in toluene) was then added and the reaction was stirred at $60{ }^{\circ} \mathrm{C}$ for 20 hours in a sealed tube. The reaction was cooled to room temperature and methanol was slowly added, forming a white precipitate. The mixture was diluted with $\mathrm{DCM}(100 \mathrm{~mL})$ and $\mathrm{MeOH}(10 \mathrm{~mL})$ and filtered through celite. The filtrate was concentrated and the residue purified via silica gel chromatography $(\mathrm{DCM} / \mathrm{MeOH}$; $0-5 \%$ gradient) to provide title compound as a brown oil. ${ }^{1} \mathrm{H} \mathrm{NMR}\left(400 \mathrm{MHz}, \mathrm{CDCl}_{3}\right) \delta 7.99$ (dd, J=1.32, $4.84 \mathrm{~Hz}, 1 \mathrm{H}), 7.84(\mathrm{~d}, J=2.64 \mathrm{~Hz}, 1 \mathrm{H}), 7.06-7.12(\mathrm{~m}, 1 \mathrm{H}), 6.70$ (ddd, $J=1.54,2.97,8.25 \mathrm{~Hz}, 1 \mathrm{H}), 4.04(\mathrm{t}, J=7.48$ $\mathrm{Hz}, 2 \mathrm{H}), 3.55(\mathrm{dd}, J=5.72,7.04 \mathrm{~Hz}, 2 \mathrm{H}), 3.02(\mathrm{~s}, 3 \mathrm{H}), 2.96(\mathrm{~s}, 3 \mathrm{H}), 2.77-2.89(\mathrm{~m}, 1 \mathrm{H}), 2.33(\mathrm{t}, J=7.48 \mathrm{~Hz}, 2 \mathrm{H})$, 2.01 (q, J=7.48 Hz, 2H). Chemical Formula: C13H19N3O, LCMS (ESI) m/z: [M+H] calcd: 233. 2; found: 234.1.

Synthesis of N,N-dimethyl-4-(1-(pyridin-3-yl)azetidin-3-yl)butanamide. (9)

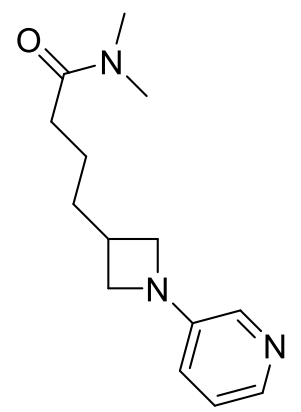

(9)

$\mathrm{N}, \mathrm{N}$-dimethyl-4-(1-(pyridin-3-yl)azetidin-3-yl)butanamide 9 was synthesized in an analogous fashion as N,N-dimethyl-3-(1-(pyridin-3-yl)azetidin-3-yl)propenamide $\mathbf{8}$ starting from TERT-BUTYL 3-(2OXOETHYL)AZETIDINE-1-CARBOXYLATE. Yield: $280 \mathrm{mg}, 1.13 \mathrm{mmol}, 56.2 \% .{ }^{1} \mathrm{H} \mathrm{NMR}\left(400 \mathrm{MHz}, \mathrm{CDCl}_{3}\right) \delta$ 7.97 (dd, J=1.32, $4.40 \mathrm{~Hz}, 1 \mathrm{H}), 7.83(\mathrm{~d}, J=2.64 \mathrm{~Hz}, 1 \mathrm{H}), 7.08(\mathrm{dd}, J=4.62,8.14 \mathrm{~Hz}, 1 \mathrm{H}), 6.66-6.72(\mathrm{~m}, 1 \mathrm{H})$, $4.03(\mathrm{t}, J=7.26 \mathrm{~Hz}, 2 \mathrm{H}), 3.50-3.57(\mathrm{~m}, 2 \mathrm{H}), 3.00(\mathrm{~s}, 3 \mathrm{H}), 2.95(\mathrm{~s}, 3 \mathrm{H}), 2.71-2.84(\mathrm{~m}, 1 \mathrm{H}), 2.33(\mathrm{t}, J=7.04 \mathrm{~Hz}$, 2H), 1.59-1.75 (m, 4H). Chemical Formula: C14H21N3O, LCMS (ESI) m/z: [M+H] calcd: 247.2; found: 248.1. 
Synthesis of 4-(hydroxymethyl)-1-(pyridin-3-yl)pyrrolidin-2-one (15)

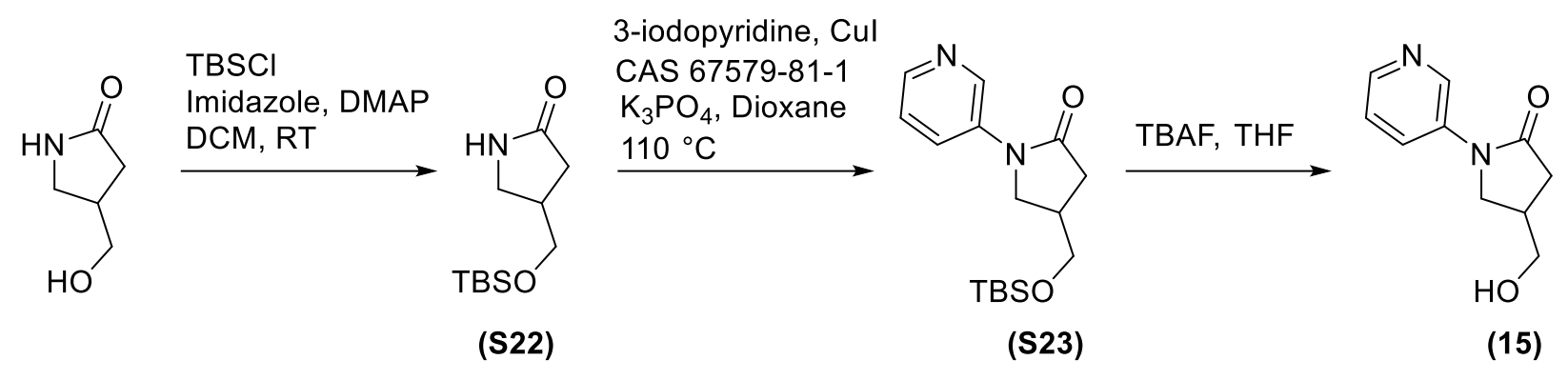

Step 1: Synthesis of 4-(((tert-butyldimethylsilyl)oxy)methyl)pyrrolidin-2-one (S22)

A solution of 4-(hydroxymethyl)pyrrolidin-2-one $(557 \mathrm{mg}, 4.84 \mathrm{mmol})$, tert-Butyldimethylsilyl chloride (802 $\mathrm{mg}, 5.32 \mathrm{mmol})$, dimethylaminopyridine $(29.6 \mathrm{mg}, 0.242 \mathrm{mmol})$ in dichloromethane $(24.2 \mathrm{~mL})$ under nitrogen was stirred at ambient temperature for 66 hours. The reaction was diluted with water $(75 \mathrm{~mL})$, dichloromethane $(50 \mathrm{~mL})$ and sodium bicarbonate $(25 \mathrm{~mL}$, saturated aqueous). The organics were removed and the aqueous washed with dichloromethane $(2 \times 50 \mathrm{~mL})$. The organics were combined and washed with brine, dried over anhydrous sodium sulfate, filtered and concentrated. The residue was purified via silica gel (Heptane/Ethyl Acetate, 0-100\% gradient) to provide title compound. Yield: 1.05 g, $4.38 \mathrm{mmol}, 90.6 \%$. ${ }^{1} \mathrm{H}$ NMR (CHLOROFORM-d, $\left.400 \mathrm{MHz}\right) \delta 6.35$ (br s, 1H), 3.5-3.6 (m, 2H), 3.45 (dd, $1 \mathrm{H}, J=8.2,9.4 \mathrm{~Hz}$ ), $3.22(\mathrm{dd}, 1 \mathrm{H}, J=5.5,9.8 \mathrm{~Hz}), 2.6-2.7(\mathrm{~m}, 1 \mathrm{H}), 2.3-2.4(\mathrm{~m}, 1 \mathrm{H}), 2.13(\mathrm{dd}, 1 \mathrm{H}, J=6.6,17.2$ $\mathrm{Hz}), 0.8-0.9(\mathrm{~m}, 9 \mathrm{H}), 0.0-0.1(\mathrm{~m}, 6 \mathrm{H})$. Chemical Formula: C11H23NO2Si, LCMS (ESI) $\mathrm{m} / \mathrm{z}$ : $[\mathrm{M}+\mathrm{H}]$ calcd: 229.2; found: 230.2 .

Step 2: Synthesis of 4-((tert-butyldimethylsilyl)oxy)methyl)-1-(pyridin-3-yl)pyrrolidin-2-one (S23)

A vial containing Cul (5.57 mg, $0.0292 \mathrm{mmol})$, (S22) $(73.9 \mathrm{mg}, 0.322 \mathrm{mmol})$ and $\mathrm{K}_{3} \mathrm{PO}_{4}(133 \mathrm{mg}, 0.537$ $\mathrm{mmol}$ ) was backfilled with nitrogen. A solution of Trans- $\mathrm{N}, \mathrm{N}^{\prime}$-dimethylcyclohexane-1,2-diamine (3.82, $0.0268 \mathrm{mmol})$. 3-iodopyridine $(55 \mathrm{mg}, 0.27 \mathrm{mmol})$ in dioxane $(0.268 \mathrm{~mL}$ ) was added the reaction was heated at $110^{\circ} \mathrm{C}$ for 5 hours. The reaction was then cooled to RT and diluted with dichloromethane ( 25 $\mathrm{mL})$, water $(25 \mathrm{~mL})$ and sodium bicarbonate $(10 \mathrm{~mL}$, saturated aqueous). The organics were removed and the aqueous washed with dichloromethane $(2 \times 25 \mathrm{~mL})$. The organics were combined, washed with brine and dried over anhydrous sodium sulfate. The solvent was removed and the residue purified via silica gel (Hetpane/Ethyl Acetate, 0-100\% gradient) to provide title compound. Yield: $78 \mathrm{mg}, 0.255 \mathrm{mmol}, 95 \% .{ }^{1 \mathrm{H}}$ NMR (CHLOROFORM-d, $400 \mathrm{MHz}) \delta 8.72(\mathrm{~d}, 1 \mathrm{H}, J=2.5 \mathrm{~Hz}$ ), $8.40(\mathrm{dd}, 1 \mathrm{H}, J=1.2,4.7 \mathrm{~Hz}), 8.2-8.3(\mathrm{~m}, 1 \mathrm{H})$, $7.31(\mathrm{dd}, 1 \mathrm{H}, J=4.7,8.4 \mathrm{~Hz}$ ), $3.95(\mathrm{dd}, 1 \mathrm{H}, J=7.9,9.5 \mathrm{~Hz}), 3.74(\mathrm{dt}, 2 \mathrm{H}, J=4.8,10.4 \mathrm{~Hz}), 3.6-3.7(\mathrm{~m}, 1 \mathrm{H}), 2.7-$ $2.8(\mathrm{~m}, 2 \mathrm{H}), 2.4-2.5(\mathrm{~m}, 1 \mathrm{H}), 0.89(\mathrm{~s}, 9 \mathrm{H}), 0.07(\mathrm{~d}, 6 \mathrm{H}, \mathrm{J}=2.3 \mathrm{~Hz})$. Chemical Formula: C16H26N2O2Si, LCMS (ESI) $\mathrm{m} / \mathrm{z}:[\mathrm{M}+\mathrm{H}]$ calcd: 306.2 ; found: 307.2

Step 3: Synthesis of 4-(hydroxymethyl)-1-(pyridin-3-yl)pyrrolidin-2-one (15)

To a solution of (S23) $(78 \mathrm{mg}, 0.25 \mathrm{mmol})$ in tetrahydrofuran $(2.55 \mathrm{~mL})$ was added tetrabutylammonium fluoride $(133 \mathrm{mg}, 0.509 \mathrm{mmol}, 1.0 \mathrm{M}$ in THF). The reaction was stirred at ambient temperature for 4 hours and partitioned between ethyl acetate, brine and water. The organic phase was washed with brine and dried over anhydrous sodium sulfate, filtered and concentrated. The residue was purified via silica gel (Heptane/Ethyl Acetate, gradient 20-100\%) to provide title compound. Yield: $47 \mathrm{mg}, 0.245 \mathrm{mmol}$, 
96\%. ${ }^{1} \mathrm{H}$ NMR (DMSO- $\left.\mathrm{d}_{6}, 600 \mathrm{MHz}\right) \delta 8.05(\mathrm{~d}, 1 \mathrm{H}, \mathrm{J}=2.1 \mathrm{~Hz}), 7.5-7.5(\mathrm{~m}, 1 \mathrm{H}), 7.28(\mathrm{br} \mathrm{dd}, 1 \mathrm{H}, J=1.2,7.3 \mathrm{~Hz})$, $6.58(\mathrm{dd}, 1 \mathrm{H}, J=4.7,8.2 \mathrm{~Hz}), 4.06(\mathrm{t}, 1 \mathrm{H}, J=5.1 \mathrm{~Hz}), 3.12(\mathrm{t}, 1 \mathrm{H}, J=8.8 \mathrm{~Hz}), 2.83(\mathrm{dd}, 1 \mathrm{H}, J=5.0,9.7 \mathrm{~Hz}), 2.6-$ $2.7(\mathrm{~m}, 2 \mathrm{H}), 1.8-1.8(\mathrm{~m}, 1 \mathrm{H}), 1.7-1.8(\mathrm{~m}, 1 \mathrm{H}), 1.51(\mathrm{dd}, 1 \mathrm{H}, J=5.6,16.7 \mathrm{~Hz}) .{ }^{1} \mathrm{H}$ NMR (DEUTERIUM OXIDE @ pH1 with 1N HCl, $600 \mathrm{MHz}) \delta 9.22(\mathrm{br} \mathrm{s}, 1 \mathrm{H}), 8.49(\mathrm{br} \mathrm{d}, 1 \mathrm{H}, J=8.5 \mathrm{~Hz}), 8.41(\mathrm{br} \mathrm{d}, 1 \mathrm{H}, J=5.6 \mathrm{~Hz})$, 7.9-8.0 (m, $1 \mathrm{H}), 4.0-4.1(\mathrm{~m}, 1 \mathrm{H}), 3.69(\mathrm{br} \mathrm{dd}, 1 \mathrm{H}, \mathrm{J}=5.1,9.5 \mathrm{~Hz}), 3.5-3.6(\mathrm{~m}, 2 \mathrm{H}), 2.6-2.8(\mathrm{~m}, 2 \mathrm{H}), 2.40(\mathrm{br} d d$, $1 \mathrm{H}, J=5.4,17.2 \mathrm{~Hz}$ ). Chemical Formula: $\mathrm{C} 10 \mathrm{H} 12 \mathrm{~N} 2 \mathrm{O} 2, \mathrm{GCMS} \mathrm{m} / \mathrm{z}$ : calcd: 192.1 ; found: 192.1 